\title{
Formation of Porous Apatite Layer during In Vitro Study of Hydroxyapatite-AW Based Glass Composites
}

\author{
Pat Sooksaen, ${ }^{1,2}$ Natyada Pengsuwan, ${ }^{1}$ Sittipong Karawatthanaworrakul, ${ }^{1}$ \\ and Surasak Pianpraditkul ${ }^{1}$ \\ ${ }^{1}$ Department of Materials Science and Engineering, Faculty of Engineering and Industrial Technology, \\ Silpakorn University, Nakhon Pathom 73000, Thailand \\ ${ }^{2}$ National Centre of Excellence for Petroleum, Petrochemicals and Advanced Materials, Chulalongkorn University, \\ Bangkok 10330, Thailand
}

Correspondence should be addressed to Pat Sooksaen; sooksaen_p@su.ac.th

Received 20 April 2015; Revised 28 June 2015; Accepted 29 June 2015

Academic Editor: Mohindar S. Seehra

Copyright (C) 2015 Pat Sooksaen et al. This is an open access article distributed under the Creative Commons Attribution License, which permits unrestricted use, distribution, and reproduction in any medium, provided the original work is properly cited.

\begin{abstract}
This research discussed the fabrication, characterization, and in vitro study of composites based on the mixture of hydroxyapatite powder and apatite-wollastonite (AW) based glass. AW based glass was prepared from the $\mathrm{SiO}_{2}-\mathrm{CaO}-\mathrm{MgO}-\mathrm{P}_{2} \mathrm{O}_{5}-\mathrm{CaF}{ }_{2}$ glass system . This study focuses on the effect of composition and sintering temperature that influences the properties of these composites. Microstructural study revealed the formation of apatite layer on the composite surfaces when immersed in simulated body fluid (SBF) solution at $37^{\circ} \mathrm{C}$. Composites containing $\geq 50 \mathrm{wt} \% \mathrm{AW}$ based glass showed good bioactivity after 7 days of immersion in the SBF. A porous calcium phosphate (potentially hydroxycarbonate apatite, HCA) layer formed at the SBF-composite interface and the layer became denser at longer soaking period, for periods ranging from 7 to 28 days. Inductively Coupled Plasma-Optical Emission Spectroscopy (ICP-OES) analysis showed that early stage of soaking occurred with the release of Ca and Si ions from the composites and the decrease of $\mathrm{P}$ ions with slow exchange rate.
\end{abstract}

\section{Introduction}

Ceramics for the reconstruction, fixation, and repair of the diseased or broken parts of the musculoskeletal system are known to possess properties such as bioinertness, for example, zirconia and alumina, bioresorption (e.g., $\beta$-tricalcium phosphate), bioactivity (e.g., hydroxyapatite, bioglass, and bioactive glass-ceramics), or porosity for tissue ingrowth (hydroxyapatite-coated alumina) [1-3]. Compositions of such materials can be engineered to obtain desired phases and properties for various applications. Calcium phosphate based bioceramics have been studied as potential substitutes for hard tissue because of their superior bioactivity, excellent biocompatibility, and osteoconductivity. Calcium phosphate $(\mathrm{CaP})$ based materials are often used in conjunction with different biomolecules to provide surfaces for adsorption and catalysis of biochemical reactions. Adsorption of molecules to $\mathrm{CaP}$ surfaces is also dependent on the solubility of the system, in addition to the microstructures (surface area and porosity). One of the most widely used synthetic calcium phosphate ceramics is hydroxyapatite (HA) due to its chemical similarity to the inorganic component of hard tissues [2-5]. Hydroxyapatite $\left(\mathrm{Ca}_{10}\left(\mathrm{PO}_{4}\right)_{6}(\mathrm{OH})_{2}\right)$ and $\beta$-tricalcium phosphate $\left(\mathrm{Ca}_{3}\left(\mathrm{PO}_{4}\right)_{2}\right)$ and their derivatives and combinations are the most commonly used ceramics in orthopaedics. Hydroxyapatite ceramic materials provide an osteoconductive matrix for bone ingrowth, but slow in vivo resorption can potentially limit their clinical applications. $\beta$-Tricalcium phosphate has been reported for biocompatibility, osteoconductivity, and resorbability but there has been limited data regarding longterm outcome of its clinical use for bone tumors.

Hench [2] first developed glasses which show bioactivity in the $\mathrm{Na}_{2} \mathrm{O}-\mathrm{CaO}-\mathrm{SiO}_{2}-\mathrm{P}_{2} \mathrm{O}_{5}$ system and named these glasses bioglass. Glass-ceramics are polycrystalline ceramics prepared by the controlled crystallization of glasses [6]. Bioactive glass-ceramics are a very promising class of 
biomaterials which have been successfully applied to the reconstruction and repair of damaged hard tissues of humans. Apatite-wollastonite (AW) glass-ceramic comprises apatite and wollastonite microcrystalline phases embedded in a glassy matrix. Dense AW glass-ceramic has been reported to have high mechanical strength as well as the capacity to form strong chemical bonds with bone tissue in human. The increase in the mechanical properties is attributed to wollastonite precipitation in the glass matrix. AW glassceramic has been used in some medical applications, either in a powder form as bone filler or as a bulk material. In addition, it exhibits high bioactivity and biocompatibility compared to microcrystalline HA [6-8]. This property is attributed to the presence of silicon, which could play an essential role in the metabolic events which induces new bone formation. Since silicon is critical in promoting apatite deposition in SBF synthetically (in vitro), mechanical properties of HA can be dramatically increased by the incorporation of glassy phase during its sintering process [9-12]. Hydroxyapatite powder compaction cannot be sintered solely to obtain dense and strong ceramic body and it is unstable above $1100^{\circ} \mathrm{C}$ in which it decomposes to $\beta$-tricalcium phosphate $(\beta$-TCP) and calcium oxide. Therefore, in this study, sintering temperature lower than $1200^{\circ} \mathrm{C}$ was necessary for the stability of such hydroxyapatite phase. The use of AW based glass would help in the sintering process to form strong porous ceramic bodies as well as providing good bioactivity functions.

The aim of the research was to investigate the in vitro test surface bioactivity of the composites prepared from sintering the mixture of high purity AR grade microcrystalline HA powder and AW based glass powder, which was synthesized in-house, to obtain strong porous composite bodies. Bioactive implant materials with porous microstructure would provide channels for tissue ingrowth and improve the microscopic bioresorption [10-12]. The composites were expected to give good combination of porous structure from HA powder and high bioactivity from AW glass crystallization [13-17]. XRD, SEM, FTIR, and ICP-EOS were utilized to obtain information on phase formation, microstructure, and bioactivity.

\section{Materials and Methods}

Apatite-wollastonite (AW) based glass of composition $36 \mathrm{SiO}_{2}-47 \mathrm{CaO}-11 \mathrm{P}_{2} \mathrm{O}_{5}-5 \mathrm{MgO}-1 \mathrm{CaF}_{2}[11,13]$ was prepared using reagent grade high purity $(>99 \%)$ chemicals. The glass batch was melted in a high-alumina crucible at $1500^{\circ} \mathrm{C}$ for $2 \mathrm{~h}$ using a bottom-loading electric furnace followed by quenching in water to retard uncontrolled devitrification. The resulting clear glass frit was ball milled to give a fine glass powder using alumina grinding media. The glass powder was later sieved through $180 \mu \mathrm{m}$ mesh size and washed with hot water and then oven-dried. Mixing of the fine glass powder with hydroxyapatite (HA) powder (HA: Sigma-Aldrich, assay $>95 \%, \leq 5 \%$ water, $\leq 10 \%$ loss on ignition, $800^{\circ} \mathrm{C}$ ) was performed using agate pestle and mortar to give the designed compositions. The authors, however, are concerned that high purity HA powder could
TABLE 1: Compositions of HA-AW composites.

\begin{tabular}{lcc}
\hline \multirow{2}{*}{ Sample } & \multicolumn{2}{c}{ Composite composition (wt\%) } \\
& Hydroxyapatite powder & AW based glass powder \\
\hline AW05 & 95 & 5 \\
AW10 & 90 & 10 \\
AW20 & 80 & 20 \\
AW40 & 60 & 40 \\
AW50 & 50 & 50 \\
AW60 & 40 & 60 \\
AW80 & 20 & 80 \\
AW90 & 10 & 90 \\
AW95 & 5 & 95 \\
\hline
\end{tabular}

Note: AW $x x=x x$ wt $\%$ of AW based glass.

come in various particle size ranges and purity and this would affect the properties. The compositions are shown in Table 1 . The mixtures were hydraulically pressed into pellets with $10 \mathrm{~mm}$ diameter and $5 \mathrm{~mm}$ thickness at $120 \mathrm{MPa}$. The pellets were transferred to alumina boat and sintered in an oxidation furnace using a heating rate of $5^{\circ} \mathrm{C} / \mathrm{min}$ until maximum soaking temperature was reached. The maximum sintering temperatures varied from 800 to $1200^{\circ} \mathrm{C}$ with $2 \mathrm{~h}$ holding time at each maximum temperature. Samples were then cooled naturally in the furnace to obtain porous strong composites for characterization.

XRD (Rigaku, Miniflex II) using $\mathrm{Cu} \mathrm{K} \alpha$ radiation, $\lambda=$ $1.5406 \AA$, and $2^{\circ} / \mathrm{min}$ scan speed was used to characterize phase composition. The analysis was initially performed on the compressed pellets of AW based glass powder which have been heat-treated from 800 to $1200^{\circ} \mathrm{C}$ to check for apatitewollastonite phase evolution during crystallization and to study phase composition after sintering the composite pellets.

Bulk density was measured using a 4-digit balance and a micrometer screw gauge. Relative density was calculated by dividing the bulk density by the theoretical density. Theoretical density was obtained by summation of weight ratio of each component multiplied by its theoretical density in the composition of composite.

The surface morphology was observed by a scanning electron microscope (Camscan SEM MX2000, UK). The porous hydroxycarbonate apatite layer formation was semiquantitatively investigated.

Evaluation of bioactivity in simulated body fluid (SBF) was carried out by soaking samples in $60 \mathrm{~mL}$ SBF solution at $37^{\circ} \mathrm{C}$. The SBF solution had a $\mathrm{pH}$ of 7.40 with ion concentrations nearly equal to those found in human blood plasma but did not contain any cells or protein. This was prepared according to Kokubo and Takadama [18] as shown in Table 2. The functional groups on the surface of the samples soaked in the SBF solution were investigated by Fourier-transform infrared (FTIR) spectroscopy (Bruker, Vertex 70). Chemical bonds in different environments will absorb energy at varying intensity and frequency. The frequencies at which there are absorptions of IR radiation can be correlated to bond types within the substance [19-21].

The concentrations of $\mathrm{Ca}, \mathrm{Si}$, and $\mathrm{P}$ ions released into the SBF solution after soaking were measured in order to 
TABLE 2: Ion concentration of SBF solution in comparison with human blood plasma [18].

\begin{tabular}{lccccccc}
\hline \multirow{2}{*}{ Types } & \multicolumn{6}{c}{ Ion concentrations (mM) } \\
& $\mathrm{Na}^{+}$ & $\mathrm{K}^{+}$ & $\mathrm{Mg}^{2+}$ & $\mathrm{Ca}^{2+}$ & $\mathrm{Cl}^{-}$ & $\mathrm{HCO}_{3}{ }^{-}$ & $\mathrm{HPO}_{4}{ }^{2-}$ \\
\hline $\begin{array}{l}\text { SBF } \\
\begin{array}{l}\text { Blood } \\
\text { plasma }\end{array}\end{array}$ & 142.0 & 5.0 & 1.5 & 2.5 & 148.8 & 4.2 & 1.0 \\
\hline
\end{tabular}

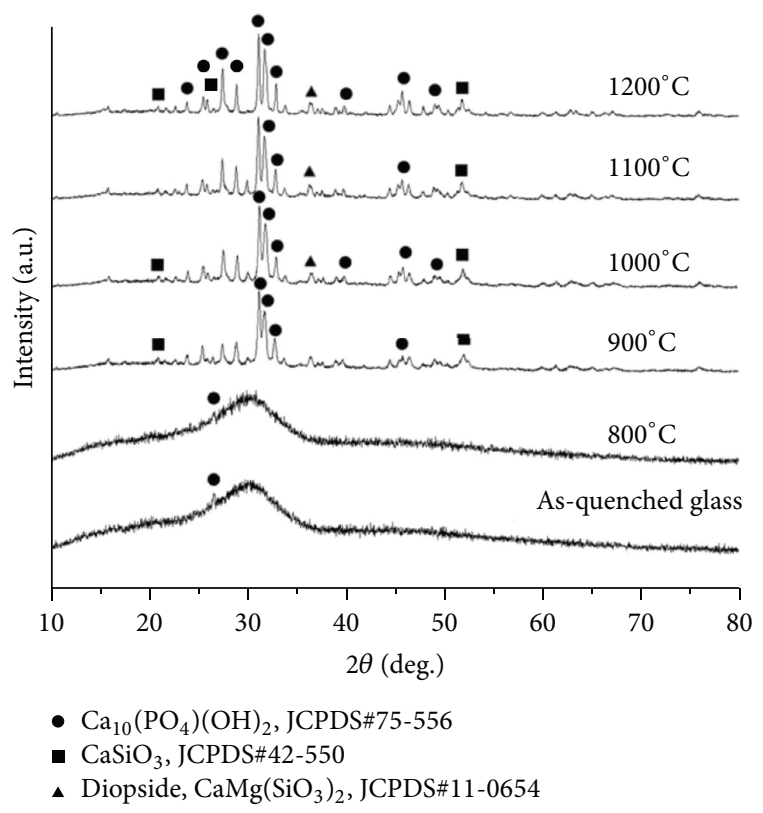

FIGURE 1: XRD patterns of AW based glass and the heat-treated samples of AW based glass at $800,900,1000,1100$, and $1200^{\circ} \mathrm{C}$ for $2 \mathrm{~h}$.

determine the ion exchange from the surface with the SBF solution [22]. This was achieved by using Inductively Coupled Plasma-Optical Emission Spectrometer (ICP-OES; Agilent Technologies, 700 series). The changes in $\mathrm{pH}$ of SBF solution were also measured at predetermined time intervals $(0,7,14$, and 28 days) using a high precision electrolyte-type $\mathrm{pH}$ meter.

\section{Results and Discussion}

3.1. Phase Analysis of AW Based Glass Crystallization. XRD patterns in Figure 1 showed phase evolution of AW based glass heat-treated at $800,900,1000,1100$, and $1200^{\circ} \mathrm{C}$ for $2 \mathrm{~h}$ using a heating rate of $5^{\circ} \mathrm{C} / \mathrm{min}$. As-quenched $\mathrm{AW}$ glass showed a broad diffraction peak which is characteristic of an amorphous material. At $800^{\circ} \mathrm{C}$, the diffraction pattern was similar to that of the as-quenched glass. This means no crystallization formed at this heat treatment temperature. Crystalline phases were clearly observed when heat-treated from above $900^{\circ} \mathrm{C}$ since the material essentially converts from a predominantly glassy material to a crystalline ceramic. Crystallization from 900 to $1200^{\circ} \mathrm{C}$ showed similar XRD patterns where apatite or hydroxyapatite phase (indicated by ๑), $\mathrm{Ca}_{10}\left(\mathrm{PO}_{4}\right)_{6}(\mathrm{OH})_{2}$ JCPDS\#75-556, appeared as a major

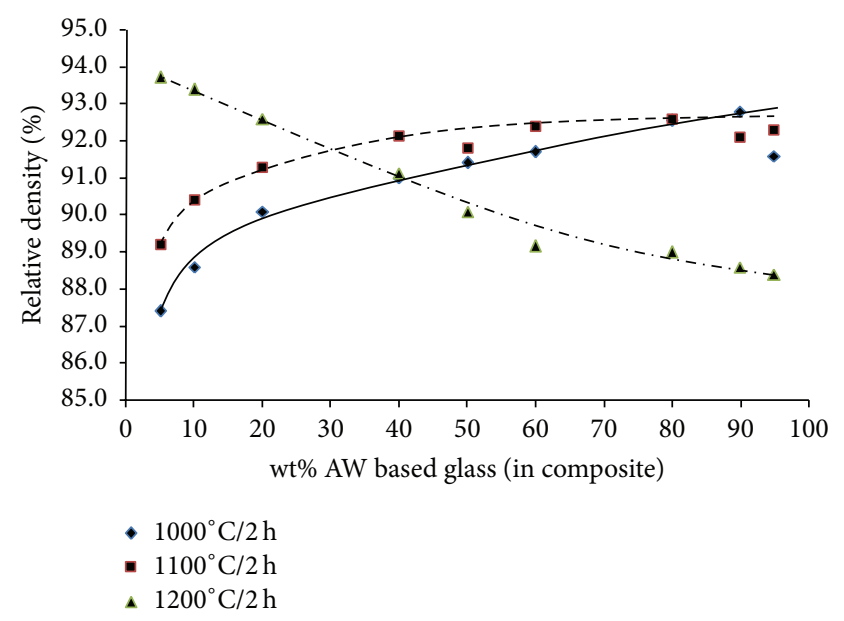

FIgURE 2: Relative densities of HA-AW composites.

phase. Small amount of wollastonite (indicated by $\mathbf{m}), \mathrm{CaSiO}_{3}$ JCPDS\#42-550, crystallized out at $900^{\circ} \mathrm{C}$ and the amount of this phase increased with increasing crystallization temperature as indicated by increasing in diffraction peak heights for this phase. Diopside (indicated by $\mathbf{\Lambda}$ ), $\mathrm{CaMg}\left(\mathrm{SiO}_{3}\right)_{2}$, also appeared as a minor phase. Both apatite and wollastonite phase are bioactive and resorbable according to Hench $[2,8]$, although the major drawback of the wollastonite $\left(\mathrm{CaSiO}_{3}\right)$ bioceramics is their relatively fast dissolution rate [8].

3.2. Relative Density. Relative densities of hydroxyapatiteAW glass composites are shown in Figure 2. The density data were shown only for samples sintered at 1000, 1100, and $1200^{\circ} \mathrm{C}$. Sintering below $1000^{\circ} \mathrm{C}$ did not give strong sintered bodies in our experiment. The pellet samples showed loose powder compaction after sintering. It can be observed that sintering at 1000 and $1100^{\circ} \mathrm{C}$ resulted in an increasing relative density when the weight percent of AW based glass was increased in the composite composition. This occurred due to glass powder acted as a sintering aid. The glass also crystallized to give apatite and wollastonite phase which are important for bioactivity and strength of the composites. Sintering at $1100^{\circ} \mathrm{C}$ gave a slightly higher relative density with respect to sintering at $1000^{\circ} \mathrm{C}$ due to higher kinetics of densification. The densities of samples sintered at $1100^{\circ} \mathrm{C}$ reached a similar value at about $92 \%$ relative density when AW based glass was $90 \mathrm{wt} \%$ in the composite composition. Sintering at $1200^{\circ} \mathrm{C}$, however, led to a decreasing trend of relative density. Compositions containing 40-95 wt $\%$ AW based glass show distorted pellets at this sintering temperature due to partial melting of glassy phase. The extent increased with higher content of AW based glass. Thermal decomposition of hydroxyapatite powder (above $1100^{\circ} \mathrm{C}$ ) also occurred, giving calcium oxide and $\beta$-tricalcium phosphate and resulting in a decrease in density of the sintered bodies.

3.3. Phase Analysis of HA-AW Composites. XRD analysis was performed on selected samples, AW05, AW50, and AW95, sintered at 1100 and $1200^{\circ} \mathrm{C}$ for $2 \mathrm{~h}$ to study phase formation. 


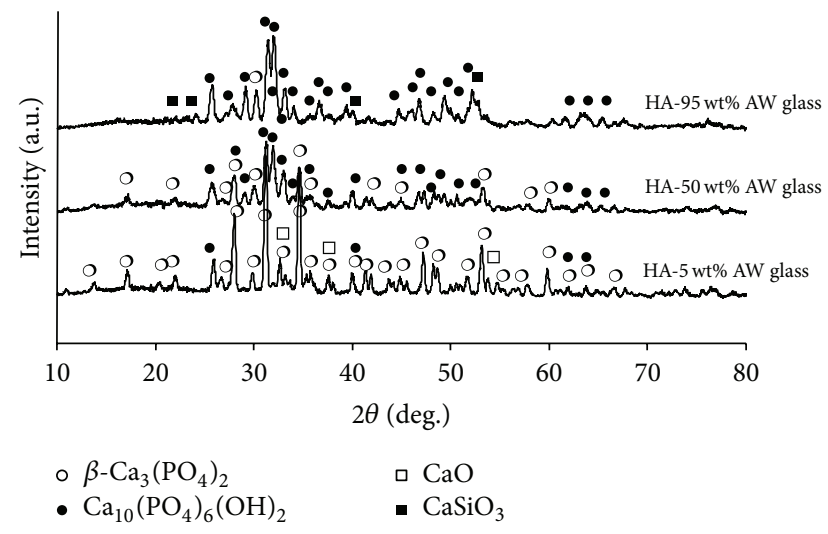

FIGURE 3: XRD patterns of HA-AW composites sintered at $1100^{\circ} \mathrm{C}$ for $2 \mathrm{~h}$.

At $1100^{\circ} \mathrm{C}$ sintering temperature, Figure 3, AW05 sample which contained higher content of hydroxyapatite powder in the composition showed a thermal decomposition into $\beta-\mathrm{Ca}_{3}\left(\mathrm{PO}_{4}\right)_{2}$, JCPDS\#9-169, or $\beta$-TCP which appeared as the major crystalline phase. This phase (indicated by $\bigcirc$ ) is bioactive and highly resorbable. Hydroxyapatite phase (indicated by ) still appeared but with lower diffraction peak intensities. Calcium oxide (CaO, JCPDS\#82-1691), indicated by $\square$, was a minor phase which appeared as a result of thermal decomposition of hydroxyapatite powder. Phases in the composite samples changed as the percentage of AW based glass in the composition increased. In AW50 sample, hydroxyapatite (indicated by $\bullet$ ) was a major crystalline phase. This phase crystallized out from AW based glass and showed a better thermal stability than hydroxyapatite powder. Diffraction peaks for $\beta$-TCP still appeared at relative higher amount in this sample. When considering AW95 sample, it can be seen that the major crystalline phases came from crystallization of AW based glass as opposed to hydroxyapatite powder. The main phases were apatite/hydroxyapatite $(\bullet)$ and wollastonite $(\mathbf{\square})$. These two phases are important for the nucleation and crystallization of porous layer of hydroxycarbonate apatite nanocrystals on the active surfaces and help increase strength of the sintered bodies. SEM analysis in Section 3.4 confirmed this characteristic. At $1200^{\circ} \mathrm{C}$ sintering temperature, Figure 4 , the relative diffraction peaks only changed slightly in intensity from those sintered at $1100^{\circ} \mathrm{C}$. The phases present in each composite composition when compared to Figures 3 and 4 were the same but only different in diffraction intensity. At $1200^{\circ} \mathrm{C}$ sintering temperature, the diffraction peaks decreased in intensity and broadened possibly due to the partial melting of the sample.

3.4. Microstructural Characterization. Samples sintered at $1100^{\circ} \mathrm{C}$ were selected for calcium phosphate or hydroxylcarbonate apatite layer formation in simulated body fluid trials. According to XRD and density measurement, this sintering temperature was sufficient to give good sinterability without loose powder compaction. This resulted in strong composites as well as the formation of stable apatite and

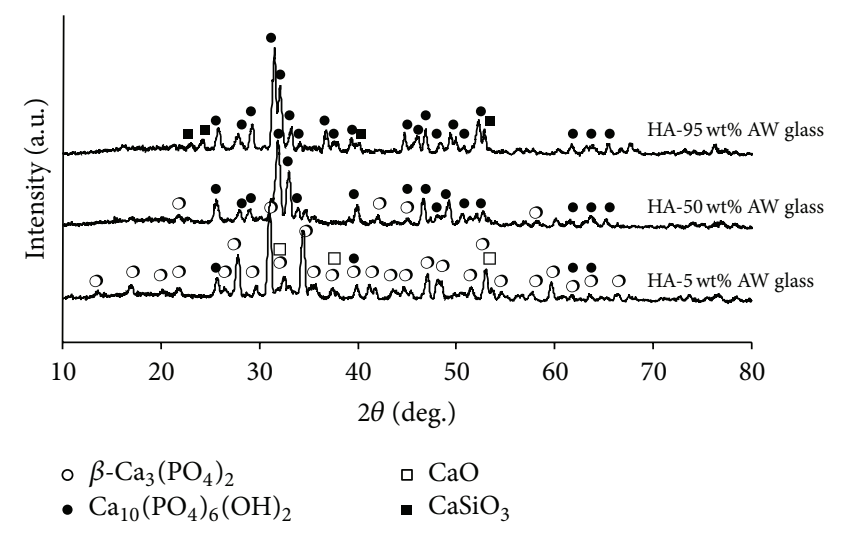

FIGURE 4: XRD patterns of HA-AW composites sintered at $1200^{\circ} \mathrm{C}$ for $2 \mathrm{~h}$.

wollastonite phase from AW based glass. Hydroxyapatite powder is unstable above $1100^{\circ} \mathrm{C}$ in which it decomposes to $\beta$-tricalcium phosphate and calcium oxide. Therefore, in this study, a sintering temperature lower than $1200^{\circ} \mathrm{C}$ was necessary for the stability of such hydroxyapatite phase.

SEM micrographs in Figure 5 were surface microstructures of AW based glass pellet (i.e., glass powder compaction without mixing hydroxyapatite powder) sintered at $1100^{\circ} \mathrm{C}$ for $2 \mathrm{~h}$. This crystallized to give apatite-wollastonite glass-ceramic. This figure showed the details before SBF immersion. It revealed smooth cleavage surfaces which are characteristics of brittle material. Micrographs shown in Figure 6 were from sample in Figure 5 after SBF immersion for 3 days at $37^{\circ} \mathrm{C}$. Small regions of nanocrystalline calcium phosphate or hydroxyl-carbonate apatite started to crystallize out. Different regions, for example, Figure 6(a) (area near the pores) and Figure 6(b) (area around the dense surface), revealed different extent of this nanocrystals formation.

Chemical composition on the surfaces was investigated by Energy Dispersive X-Ray Spectroscopy (EDS). The EDS trace in the inset of Figure 5(b) showed chemical composition of wollastonite phase in the AW glass-ceramic because it mainly consisted of Si and Ca where the EDS trace in the inset of Figure 6(b) showed chemical composition of calcium phosphate phase as indicated by higher contents of $\mathrm{P}$ and $\mathrm{Ca}$. Small characteristic X-ray peaks for $\mathrm{Mg}$ and $\mathrm{Al}$ came from silica-based residual glass.

Microstructures on the surfaces of HA-AW composites sintered at $1100^{\circ} \mathrm{C}$ for $2 \mathrm{~h}$ before and after soaking in the SBF solution at $37^{\circ} \mathrm{C}$ for 7 and 28 days are shown in Figure 7. Samples with 5, 50, and 95\% AW based glass in the compositions (i.e., AW05, AW50, and AW95) were selected to represent the results and were discussed thoroughly. SEM micrographs of AW05 before immersion in the SBF solution (0 days) showed spherical HA particles dispersed uniformly within the microstructure. The particles loosly packed and the composite sample contained high porosity. This porous structure could be advantageous because engineering bioactive implant materials with porous microstructure would provide channels for bone ingrowth and improve the microscopic bioresorption [2, 4]. AW50 


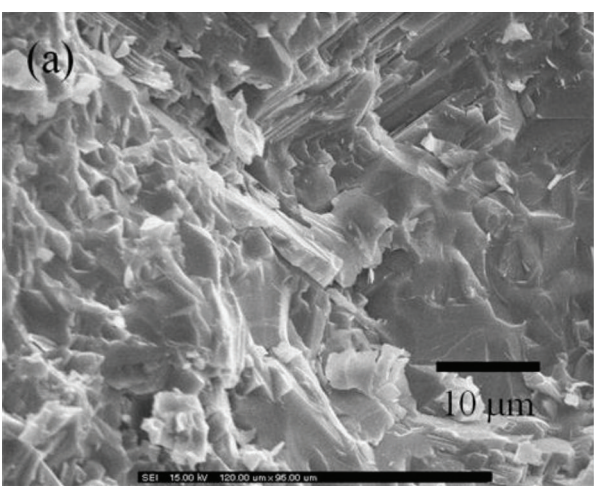

(a)

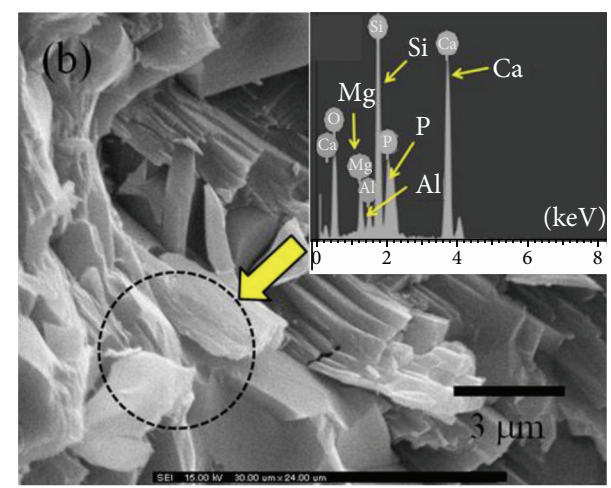

(b)

FigURE 5: Surface microstructure of AW based glass sintered at $1100^{\circ} \mathrm{C}$ for $2 \mathrm{~h}$, before SBF immersion. (a) Low magnification, scale bar $10 \mu \mathrm{m}$. (b) High magnification, scale bar $3 \mu \mathrm{m}$.

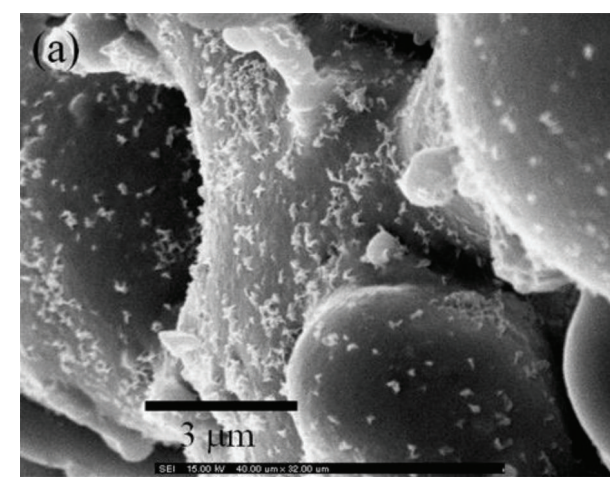

(a)

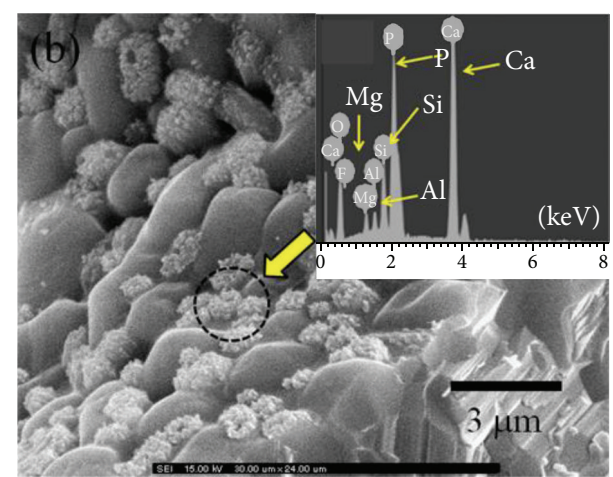

(b)

FIGURE 6: Surface microstructure of AW based glass sintered at $1100^{\circ} \mathrm{C}$ for $2 \mathrm{~h}$, after $\mathrm{SBF}$ immersion for 3 days at $37^{\circ} \mathrm{C}$. (a) Area near the pores, scale bar $3 \mu \mathrm{m}$. (b) Area around the dense surface, scale bar $3 \mu \mathrm{m}$.

before immersion in the SBF solution (0 days) showed similar microstructure to that of the AW05 but HA particles seemed to pack more densely. This occurred due to higher amount of AW based glass in the composite composition. The AW based glass crystallized to form apatite-wollastonite glassceramic above its glass transition with the remaining glassy phase acted as a sintering aid for the composite sintered at this temperature. For AW95 sample, the continuous surface layers were observed as a result of higher densification with increasing AW based glass content. The continuous phase seen in the micrograph represented the residual glassy phase in the crystallized parts of AW glass-ceramic. This highly dense structure led to a lower level of porosity and could decrease overall microscopic bioresorption. The increase of glassy phase effectively increased the packing density of HA powder due to capillary force of the liquid or viscous glass phase sintering mechanism.

On immersion in the SBF solution, the porous calcium phosphate or hydroxycarbonate apatite layers formed faster in the AW50 and AW95 samples than in the AW05 sample after 7 days. The AW05 samples started to form these porous layers after 7 days. The micrographs after 28 days of immersion for all samples showed highly dense calcium phosphate layers. The size and thickness of calcium phosphate layers increased with increasing SBF immersion time. It is clear at this stage that samples containing higher amount of AW based glass in the composites showed higher surface bioactive rate since the calcium phosphate layers formed faster in the simulated body fluid. The essential requirement for an artificial material to bond to living bone is the formation of this calcium phosphate layer on the surfaces. This layer is similar to bone mineral in composition and structure; hence, the bone-producing cell called an osteoblast can proliferate preferentially on this surface [2-4]. The surround bone can then come into direct contact with this layer. The calcium phosphate layer formed throughout chemical reaction of the bioactive composite with the surrounding fluid.

3.5. Fourier-Transform Infrared Spectroscopy. FTIR spectra in Figure 8 showed results for AW05 and AW95 composite samples soaked in the SBF solution for various periods of time (0-28 days). These are representative data for IR absorption bands related to chemical bond types in the structure. Similar absorption bands were observed in the composite of the same composition at any soaking time. In Figure 8(a), the intensity of absorption bands at $\sim 1038 \mathrm{~cm}^{-1}$ (Si-O-Si stretching) and 

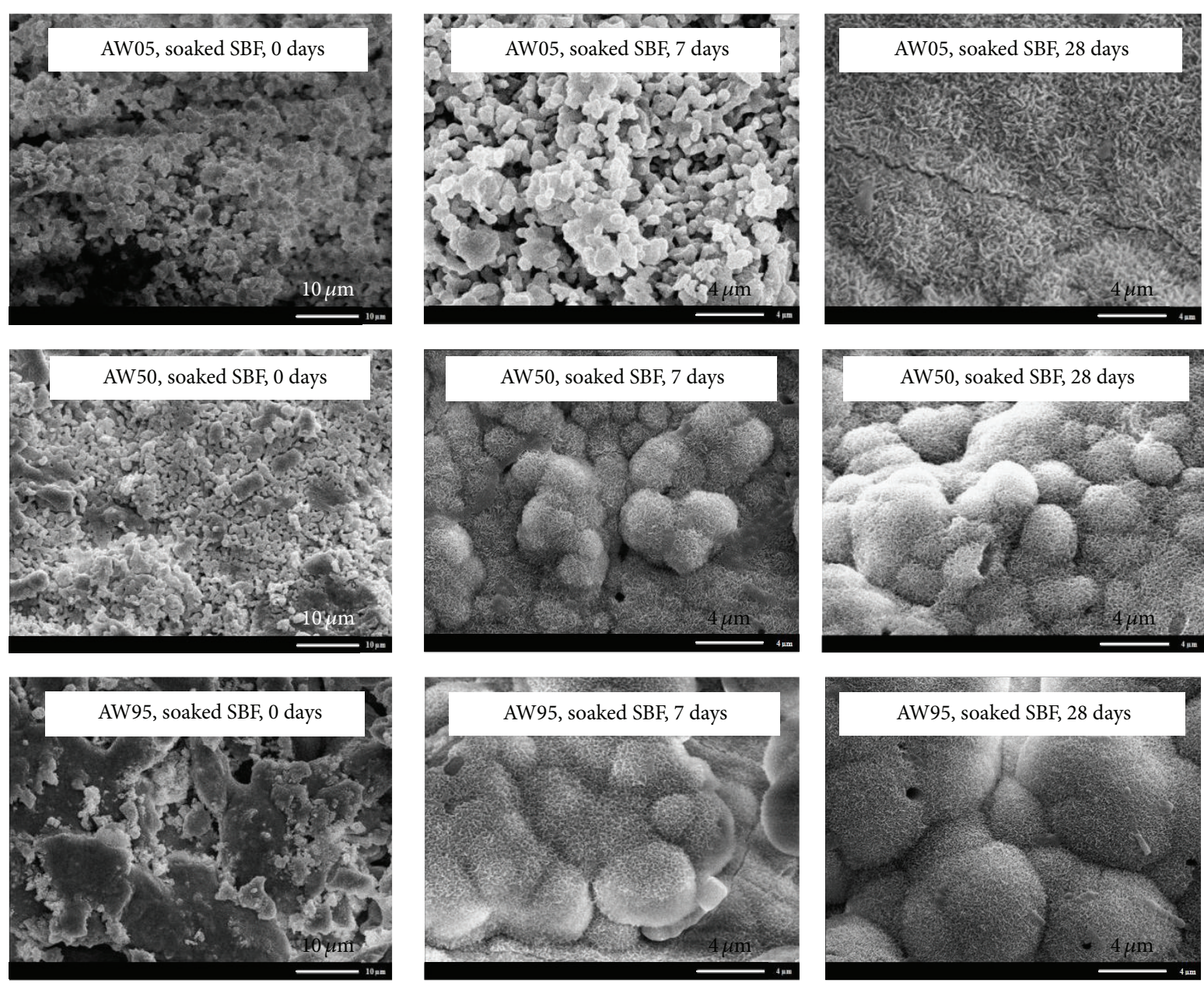

FIGURE 7: SEM micrographs on the surfaces of HA-AW composites sintered at $1100^{\circ} \mathrm{C}$ for $2 \mathrm{~h}$, before and after soaking in the SBF solution at $37^{\circ} \mathrm{C}$ for 7 and 28 days.

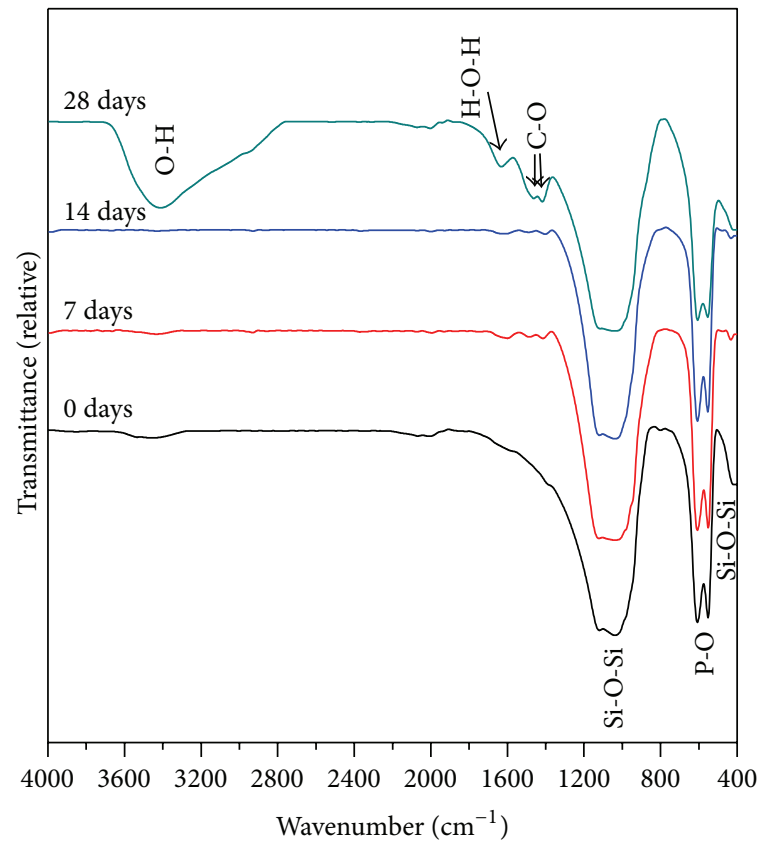

(a)

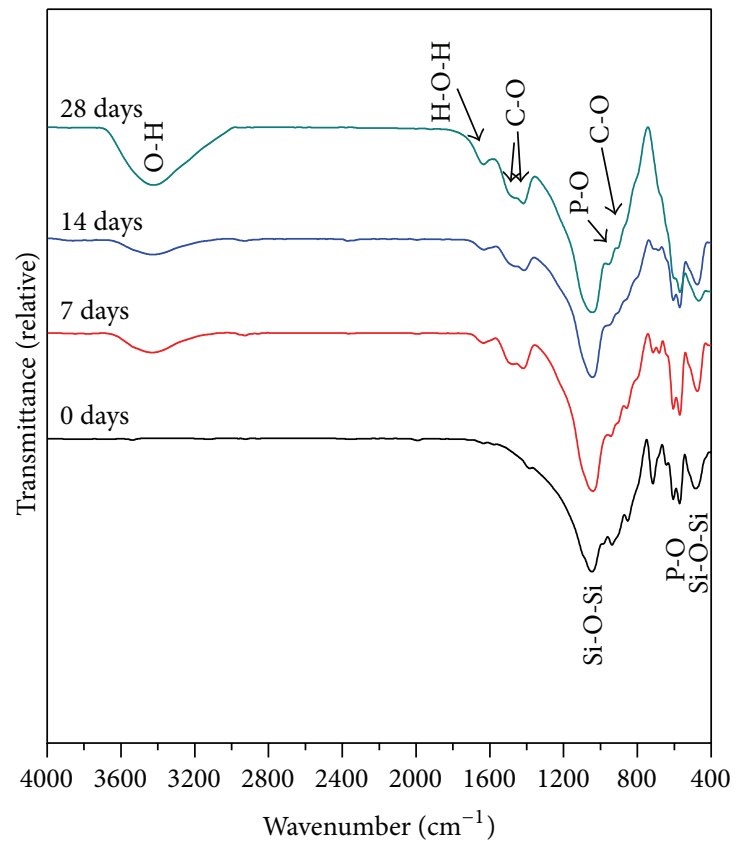

(b)

FIGURE 8: FTIR spectra of composites, (a) AW05 and (b) AW95, soaked in the SBF solution for various periods of time. 


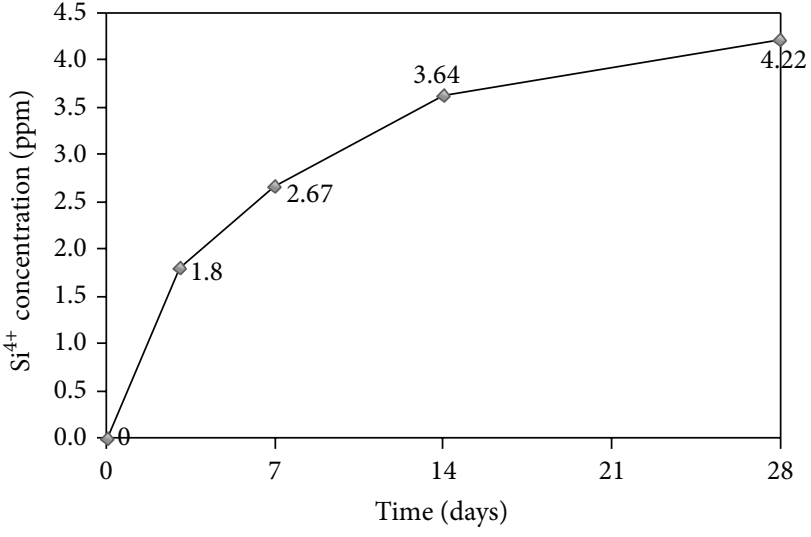

(a)

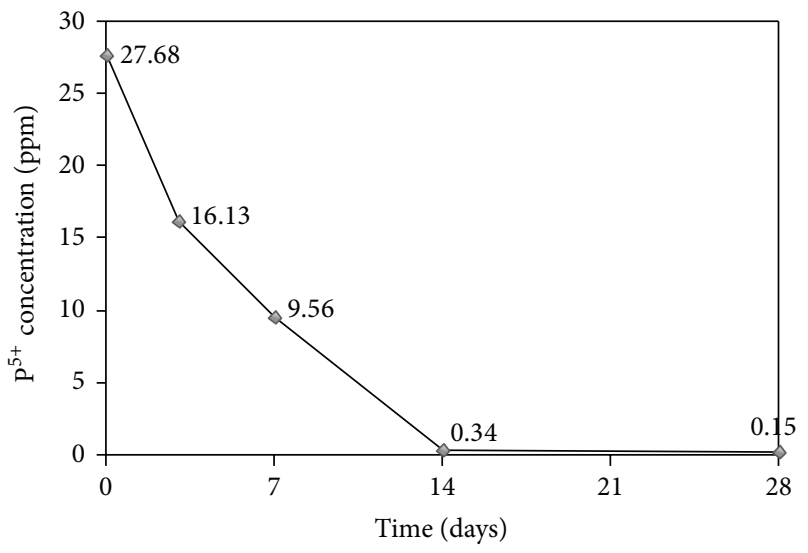

(c)

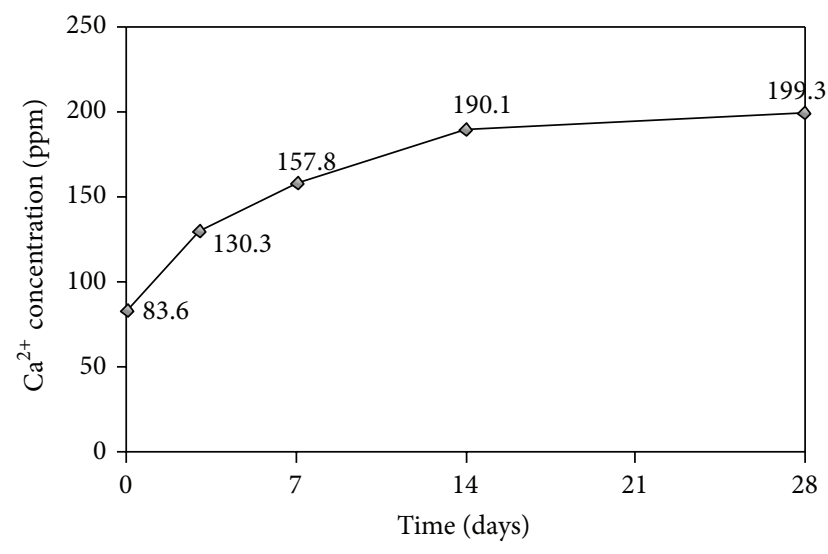

(b)

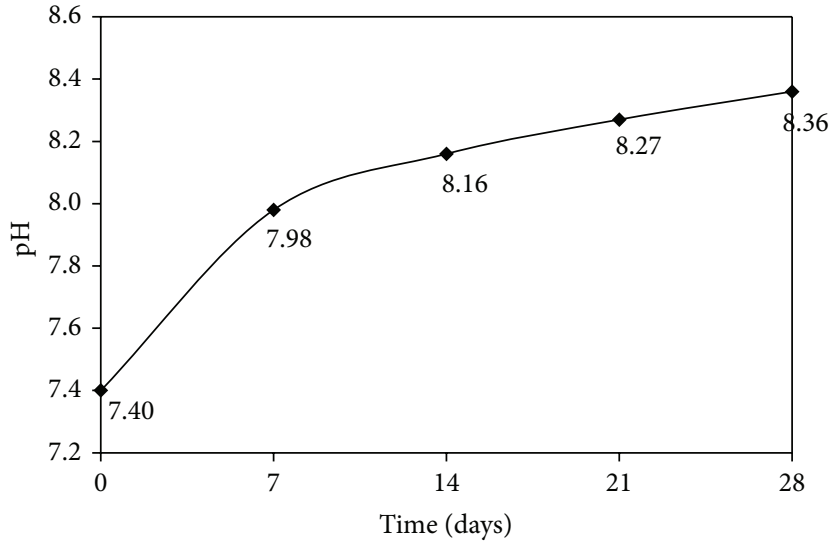

(d)

Figure 9: Changes in ion concentration, (a) $\mathrm{Si}^{4+}$ ion, (b) $\mathrm{Ca}^{2+}$ ion, and (c) $\mathrm{P}^{5+}$ ion, and (d) $\mathrm{pH}$ of the SBF solution, after soaking AW95 (sintered at $1100^{\circ} \mathrm{C}$ for $2 \mathrm{~h}$ ) at various time intervals during bioactivity test.

$474 \mathrm{~cm}^{-1}$ (Si-O-Si bending) decreased when the soaking time increased. Two absorption bands responsible for the calcium phosphate phase occurred at around 604 and $565 \mathrm{~cm}^{-1}$, assigned as $\mathrm{P}-\mathrm{O}$ bending vibration $[21,23]$. With increasing immersion time, absorption bands related to $\mathrm{O}-\mathrm{H}, \mathrm{C}-\mathrm{O}$, and $\mathrm{P}-\mathrm{O}$ were clearly observed. The absorptions at 3500$2700 \mathrm{~cm}^{-1}$ and $1621 \mathrm{~cm}^{-1}$ can be assigned to hydroxyl groups in the hydroxyapatite. The absorptions at about 1462 and $1420 \mathrm{~cm}^{-1}$ fitted well with the carbonate groups in apatite structure. The absorptions around $880 \mathrm{~cm}^{-1}$ were due to $\mathrm{CO}_{3}{ }^{2-}$ functional group. In addition, absorptions related to phosphate group were found at about 945 and $600-560 \mathrm{~cm}^{-1}$ $[21,23]$. These are the characteristic absorptions of calcium phosphate which suggest the formation of apatite layer on the surface of the samples after soaking in SBF solution. As noticed, increasing the soaking time gradually increased the intensity of $\mathrm{O}-\mathrm{H}, \mathrm{C}-\mathrm{O}$, and $\mathrm{P}-\mathrm{O}$ absorptions as a result of formation of higher amount of hydroxycarbonate apatite (HCA) on the surface. Figure 8(b) showed FTIR spectra of AW95 after soaking in the SBF. With increasing soaking time, the intensity of absorption bands became stronger, which can be related to the formation of hydroxyl-carbonate apatite on the surfaces of the samples. However, in comparison with
AW05 samples (Figure 8(a)), the absorption peaks for AW95 samples were stronger due to the higher amount of hydroxylcarbonate apatite precipitated on the surface of the samples. Overall, these findings confirmed the formation of calcium phosphate layer on the surface of all the specimens after soaking in the SBF solution.

3.6. Bioactivity Characterization by IPC-EOS. The ICP-OES analysis was performed in order to determine the concentration of the $\mathrm{Ca}^{2+}, \mathrm{P}^{5+}$, and $\mathrm{Si}^{4+}$ ions in the $\mathrm{SBF}$ solution. AW95 samples sintered at $1100^{\circ} \mathrm{C}$ for $2 \mathrm{~h}$ were selected for representative data since this composition is highly bioactive according to the results discussed earlier. Figure 9 showed that the glass phase in the composite released $\mathrm{Si}$ and $\mathrm{Ca}$ ions, indicating that calcium and silicon ions diffused out from the bulk sample to the SBF. The concentration of silicon increased continuously during the soaking from 0 to 4.22 ppm after 28 days. Glassy phase in AW glass-ceramic controls calcium phosphate layer (potentially the hydroxylcarbonate apatite) rate formation due to release of $\mathrm{Ca}$ and $\mathrm{Si}$ ions which would be greater than the hydroxyapatite powder. This helped to increase the nucleation and precipitation of porous calcium phosphate nanocrystals on the surface. The 
result is consistent with the study of Kokubo and Takadama [18] which suggested that dissolved silica plays an important role in the formation of apatite layer. The degradation of $\mathrm{Si}$ led to the formation of a porous reaction layer at the surface.

During later immersion, the concentration of $\mathrm{Ca}$ ions in the SBF solution increased and later became constant due to the precipitation of a calcium phosphate layer. The phosphorus concentration also decreased gradually. Changes during the first 2 weeks of immersion in the SBF solution were significant due to the formation of calcium phosphate layers. The diffusion process of the ions took place through the pores and easily on the boundary of the open pores of the porous reaction layer generated by the degradation of the Si-rich layer at the composite and SBF interface. The exchange between $\mathrm{H}^{+}$ions within the SBF solution and cations in the composite sample at the sample/SBF interface resulted in an increase of $\mathrm{pH}$ of SBF solution from 7.40 to 8.36 . The release of cations and the $\mathrm{pH}$ increment can be explained by the exchange mechanism proposed by Kokubo $[18,19]$ for the formation of an apatite layer on the surface.

\section{Conclusions}

The composites immersed into the SBF solution formed porous calcium phosphate layer (potentially the hydroxylcarbonate apatite). This porous layer became denser with increasing time of SBF immersion. The amount of AW based glass in the composite composition controlled the ability of calcium phosphate layer formation. Composition with less amount of AW based glass (i.e., AW05) showed highly porous composite which was not strong and the surface was less active which required $\mathrm{SBF}$ immersion time more than 7 days. AW50 and AW95 samples, though having low level of porosity, showed better bioactivity response. This occurred due to the presence of glassy phase which increased the exchange rate of related ions for calcium phosphate layer formation. The composites synthesized in this study could serve as a promising platform for regeneration of hard tissues.

\section{Conflict of Interests}

The authors declare that there is no conflict of interests regarding the publication of this paper.

\section{Acknowledgments}

The authors would like to acknowledge the Department of Materials Science and Engineering, Faculty of Engineering and Industrial Technology, Silpakorn University, and National Center of Excellence for Petroleum, Petrochemicals and Advanced Materials, Chulalongkorn University, for financial support. They also would like to thank Assistant Professor Dr. Vorrada Loryuenyong for her valuable comments and encouragement throughout this research.

\section{References}

[1] E. M. Carlisle, "Silicon: a possible factor in bone calcification," Science, vol. 167, no. 3916, pp. 279-280, 1970.

[2] L. L. Hench, "Bioceramics: from concept to clinic," Journal of the American Ceramic Society, vol. 74, no. 7, pp. 1487-1510, 1991.

[3] W. Cao and L. L. Hench, "Bioactive materials," Ceramics International, vol. 22, no. 6, pp. 493-507, 1996.

[4] S. M. Best, A. E. Porter, E. S. Thian, and J. Huang, "Bioceramics: past, present and for the future," Journal of the European Ceramic Society, vol. 28, no. 7, pp. 1319-1327, 2008.

[5] E. Fidancevska, G. Ruseska, J. Bossert, Y.-M. Lin, and A. R. Boccaccini, "Fabrication and characterization of porous bioceramic composites based on hydroxyapatite and titania," Materials Chemistry and Physics, vol. 103, no. 1, pp. 95-100, 2007.

[6] W. Höland, "Biocompatible and bioactive glass-ceramics-state of the art and new directions," Journal of Non-Crystalline Solids, vol. 219, pp. 192-197, 1997.

[7] O. Peitl, E. Dutra Zanotto, and L. L. Hench, "Highly bioactive $\mathrm{P}_{2} \mathrm{O}_{5}-\mathrm{Na}_{2} \mathrm{O}-\mathrm{CaO}-\mathrm{SiO}_{2}$ glass-ceramics," Journal of NonCrystalline Solids, vol. 292, no. 1-3, pp. 115-126, 2001.

[8] L. L. Hench, "Genetic design of bioactive glass," Journal of the European Ceramic Society, vol. 29, no. 7, pp. 1257-1265, 2009.

[9] A. J. Salinas, J. Roman, M. Vallet-Regi, J. M. Oliveira, R. N. Correia, and M. H. Fernandes, "In Vitro bioactivity of glass and glass-ceramics of the $3 \mathrm{CaO} . \mathrm{P}_{2} \mathrm{O}_{5}-\mathrm{CaO} . \mathrm{SiO}_{2}-\mathrm{CaO} \cdot \mathrm{Mg} .2 \mathrm{SiO}_{2}$ system," Biomaterials, vol. 21, no. 3, pp. 251-257, 2000.

[10] M. Magallanes-Perdomo, P. Pena, P. N. De Aza et al., "Devitrification studies of wollastonite-tricalcium phosphate eutectic glass," Acta Biomaterialia, vol. 5, no. 8, pp. 3057-3066, 2009.

[11] M. Magallanes-Perdomo, Z. B. Luklinska, A. H. De Aza, R. G. Carrodeguas, S. De Aza, and P. Pena, "Bone-like forming ability of apatite-wollastonite glass ceramic," Journal of the European Ceramic Society, vol. 31, no. 9, pp. 1549-1561, 2011.

[12] M. Vallet-Regí, I. Izquierdo-Barba, and A. J. Salinas, "Influence of $\mathrm{P}_{2} \mathrm{O}_{5}$ on crystallinity of apatite formed in vitro on surface of bioactive glasses," Journal of Biomedical Materials Research, vol. 46, no. 4, pp. 560-565, 1999.

[13] P. Sooksaen, K. Chaithep, T. Saliwong, and T. Duangart, "Apatite-wollastonite bioactive glass-ceramic scaffolds for hard tissue engineering," Advanced Materials Research, vol. 506, pp. 146-149, 2012.

[14] R. Ravarian, F. Moztarzadeh, M. S. Hashjin, S. M. Rabiee, P. Khoshakhlagh, and M. Tahriri, "Synthesis, characterization and bioactivity investigation of bioglass/hydroxyapatite composite," Ceramics International, vol. 36, no. 1, pp. 291-297, 2010.

[15] J. D. Santos, J. C. Knowles, R. L. Reis, F. J. Monteiro, and G. W. Hastings, "Microstructural characterization of glass-reinforced hydroxyapatite composites," Biomaterials, vol. 15, no. 1, pp. 5-10, 1994.

[16] C. K. Chang, D. L. Mao, and J. S. Wu, "Characteristics of crystals precipitated in sintered apatite/wollastonite glass ceramics," Ceramics International, vol. 26, no. 7, pp. 779-785, 2000.

[17] S. Padilla, J. Román, S. Sánchez-Salcedo, and M. ValletRegí, "Hydroxyapatite $/ \mathrm{SiO}_{2}-\mathrm{CaO}-\mathrm{P}_{2} \mathrm{O}_{5}$ glass materials: in vitro bioactivity and biocompatibility," Acta Biomaterialia, vol. 2, no. 3, pp. 331-342, 2006.

[18] T. Kokubo and H. Takadama, "How useful is SBF in predicting in vivo bone bioactivity?” Biomaterials, vol. 27, no. 15, pp. 29072915, 2006. 
[19] C. A. Miller, T. Kokubo, I. M. Reaney, P. V. Hatton, and P. F. James, "Formation of apatite layers on modified canasite glass-ceramics in simulated body fluid," Journal of Biomedical Materials Research, vol. 59, no. 3, pp. 473-480, 2002.

[20] X. Liu, C. Ding, and P. K. Chu, "Mechanism of apatite formation on wollastonite coatings in simulated body fluids," Biomaterials, vol. 25, no. 10, pp. 1755-1761, 2004.

[21] C. Paluszkiewicz, M. Blazewicz, J. Podporska, and T. Gumuła, "Nucleation of hydroxyapatite layer on wollastonite material surface: FTIR studies," Vibrational Spectroscopy, vol. 48, no. 2, pp. 263-268, 2008.

[22] H. A. ElBatal, M. A. Azooz, E. M. A. Khalil, A. Soltan Monem, and Y. M. Hamdy, "Characterization of some bioglassceramics," Materials Chemistry and Physics, vol. 80, no. 3, pp. 599-609, 2003.

[23] A. Stoch, W. Jastrzębski, A. Brozek et al., "FTIR absorptionreflection study of biomimetic growth of phosphates on titanium implants," Journal of Molecular Structure, vol. 555, no. 1-3, pp. 375-382, 2000. 

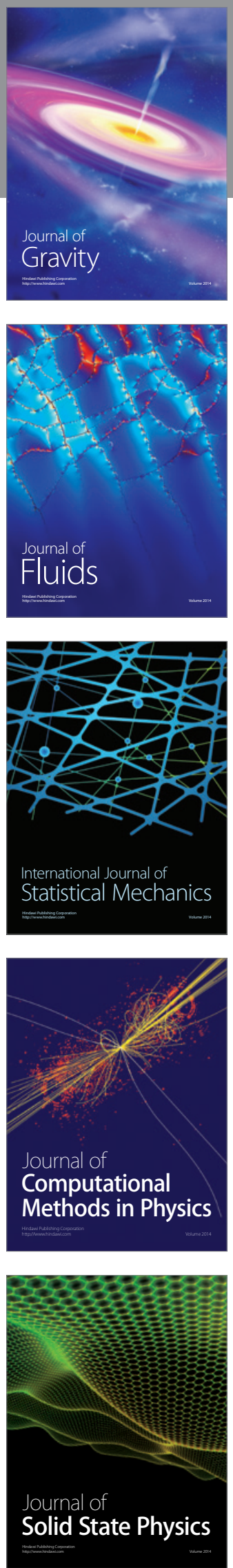

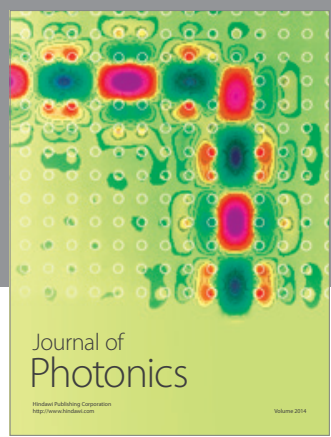

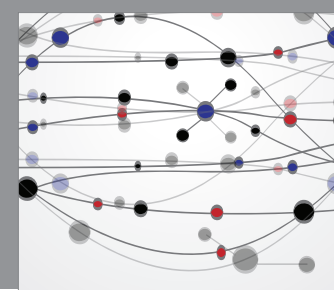

The Scientific World Journal

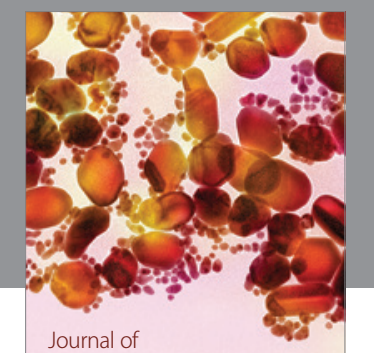

Soft Matter
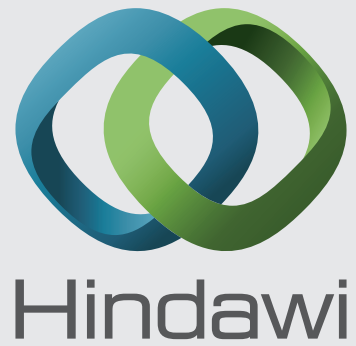

Submit your manuscripts at

http://www.hindawi.com
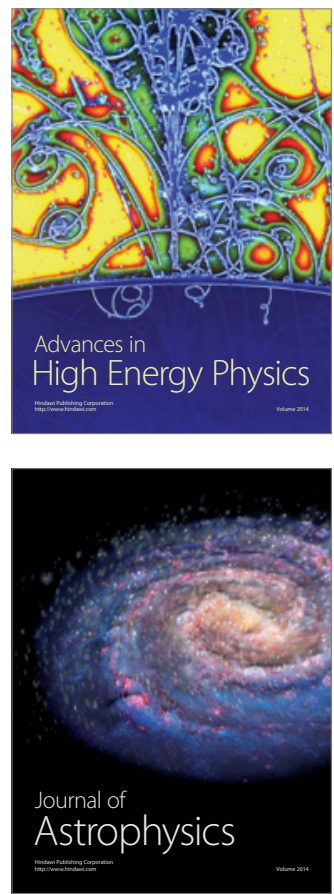
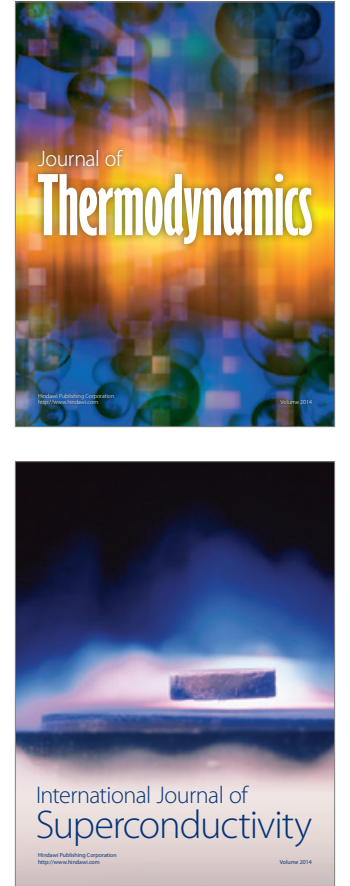
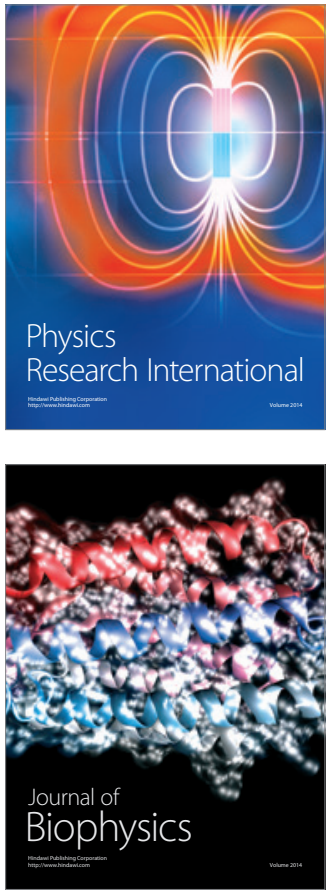
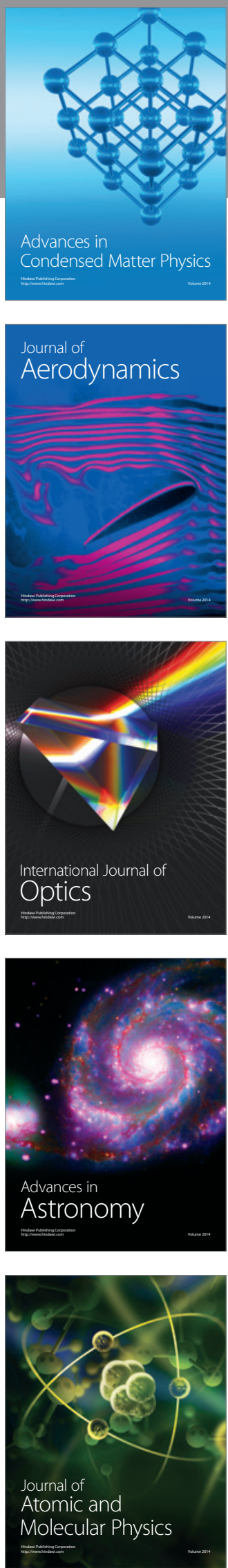